\title{
Edukasi Pentingnya Penggunaan Sunscreen pada Kalangan Remaja di SMA Islam Sabilillah Malang
}

\author{
Elva Asmiati, Rizka Novia Atmadani*, Fitria Dwi Damayanti, Risma Ayu Setiawan \\ Program Studi Farmasi, Fakultas Ilmu Kesehatan, Universitas Muhammadiyah Malang \\ *Corresponding Author. Email: rizkanovia@umm.ac.id
}

\begin{abstract}
The purpose of this community service is to provide the students knowledge about the benefits and importance of using sunscreen in everyday life. Based on the several steps of the method we used, starting from the preparation of the event, pre-test before giving the material, then giving the material through Power-point slides, post-test evaluation, and closing. Partners in this service are students at Sabilillah Islamic High School Malang. The instrument in giving the material is power point and to do the pre-test and posttest using the google form platform. The results of this service is an increase in the knowledge of the students at Sabilillah Islamic High School Malang which can be seen in the pre- and post-test scores of respondents' knowledge of the material provided. The value shows an increase from before and after the provision of material which indicates that the provision of education has succeeded in increasing knowledge for students at Sabilillah Islamic High School Malang.
\end{abstract}

\begin{abstract}
Abstrak: Tujuan pengabdian masyarakat ini adalah untuk memberikan pengetahuan siswa-siswi SMA Islam Sabilillah Malang mengenai manfaat serta pentingnya penggunaan sunscreen dalam kehidupan sehari-hari. Berdasarkan beberapa step metode dalam kegiatan penyuluhan adalah mulai dari persiapan acara, pre-test sebelum pemberian materi, kemudian pemberian materi melalui slide Power-point, post-test evaluasi, dan penutupan. Sasaran pada pengabdian ini adalah para siswa dan siswi di SMA Islam Sabilillah Malang. Instrumen dalam memberikan materi adalah power point dan untuk melakukan pre-test dan post-test menggunakan paltform google form. Hasil pengabdian ini adalah peningkatan pengetahuan dari siswa-siswi SMA Islam Sabilillah Malang yang dapat dilihat pada nilai skor pre dan post-test pengetahuan terhadap materi yang diberikan. Nilai menunjukkan kenaikan dari sebelum dan sesudah pemberian materi yang menunjukkan bahwa pemberian edukasi berhasil menambah pengetahuan bagi siswa-siswi SMA Islam Sabilillah Malang.
\end{abstract}

\section{Article History:}

Received: 13-09-2021

Reviewed: 28-09-2021

Accepted: 11-10-2021

Published: 13-11-2021

\section{Key Words: \\ Education, \\ Sunscreen, \\ Teenager.}

\section{Sejarah Artikel: \\ Diterima: 13-09-2021 \\ Direview: 28-09-2021 \\ Disetujui: 11-10-2021 \\ Diterbitkan: 13-11-2021}

\section{Kata Kunci:}

Edukasi, Sunscreen, Remaja.

How to Cite: Asmiati, E., Atmadani, R., Damayanti, F., \& Setiawan, R. (2021). Edukasi Pentingnya Penggunaan Sunscreen pada Kalangan Remaja di SMA Islam Sabilillah Malang. Jurnal Pengabdian UNDIKMA, 2(2), 189-194. doi:https://doi.org/10.33394/jpu.v2i2.4135

\section{Pendahuluan}

Remaja adalah usia dimana memiliki keinginan yang sangat tinggi untuk selalu terlihat cantik, kulit putih dan selalu melakukan perawatan diri khususnya kulit. Salah satu perawatan yang banyak dilakukan adalah penggunaan sunscreen untuk menghindari efek buruk dari radiasi sinar UV terhadap kulit. Untuk perawatan harian kulit remaja, hal paling mendasar yaitu melindungi kulit dari bahaya paparan sinar matahari. Indonesia merupakan negara tropis yang penuh dengan limpahan sinar matahari sepanjang tahunnya. Sinar matahari sendiri merupakan sumber energi yang bermanfaat bagi kehidupan manusia. Matahari dapat memancarkan berbagai macam sinar baik yang dapat dilihat (visible) maupun 
yang tidak dapat dilihat. Sinar matahari yang dapat dilihat adalah sinar yang dipancarkan dalam gelombang lebih dari 400nm, sedangkan sinar matahari dengan panjang gelombang 10nm- 400nm yang disebut dengan sinar ultra violet tidak dapat dilihat dengan mata (Isfardiyana \& Safitri, 2014)

Sinar ultra violet (UV) dapat digolongkan menjadi UV-A dengan panjang gelombang diantara 320 - $400 \mathrm{~nm}$, UV-B dengan panjang gelombang 290 - $320 \mathrm{~nm}$ dan UV-C dengan panjang gelombang $10-290 \mathrm{~nm}$. Semua Sinar UV-A di emisikan ke bumi, sedangkan sinar UV-B sebagian diemisikan ke bumi (terutama yang panjang gelombangnya mendekati UV-A. Sinar UV-B dengan panjang gelombang lebih pendek dan sinar UV-C tidak dapat diemisikan ke bumi karena diserap lapisan ozon di atmosfir bumi. Dengan demikian apabila lapisan ozon yang ada di atmosfir rusak, sinar UV-B yang masuk ke bumi akan semakin banyak. (Isfardiyana \& Safitri, 2014)

Sinar ultraviolet dalam jumlah kecil diperlukan oleh tubuh manusia, yaitu membantu pembentukan vitamin D oleh tubuh. Tetapi sinar ultraviolet dalam jumlah banyak juga dapat menyebabkan kanker kulit, kerusakan mata dan menurunkan kekebalan tubuh. Sinar UV-B dalam jumlah besar dapat merusak sel-sel hidup, khususnya sel kulit sehingga sel ini menjadi sel kanker (Cahyono, 2005).

Dari ketiga jenis sinar ultraviolet yang sudah dibahas, masing-masing memiliki ciriciri dan tingkat keparahan efek radiasi yang berbeda- beda. Namun pada umumnya, sinar ultraviolet yang terpapar masuk ke bumi, baik itu sinar UV-A, UV-B, maupun UV-C, dapat memberikan dampak seperti kemerahan pada kulit, kulit terasa terbakar, menimbulkan penyakit katarak, dapat memicu pertumbuhan sel kanker, dan lain-lain (Isfardiyana \& Safitri, 2014).

Suncreen merupakan suatu zat atau material yang dapat melindungi kulit terhadap radiasi sinar UV. Sediaan sunscreen terdapat dalam berbagai bentuk misalnya lotion untuk dioleskan pada kulit, krim, salep, gel atau spray yang diaplikasikan pada kulit. Sediaan kosmetik yang mengandung tabir surya biasanya dinyatakan dalam label dengan kekuatan SPF (Sun Protecting Factor) tertentu. Nilai SPF terletak diantara kisaran 2-60, angka ini menunjukkan seberapa lama produk tersebut mampu melindungi atau memblok sinar UV yang menyebabkan kulit terbakar. Mengaplikasikan sunscreen sebelum beraktivitas menjadi hal penting untuk mengurangi risiko terkena paparan sinar matahari. Terlebih karakter kulit orang tropis yang mudah menggelap membuat sunscreen menjadi produk esensial dalam kehidupan sehari-hari. Namun, masih banyak masyarakat Indonesia yang mengabaikan pentingnya penggunaan sunscreen (Isfardiyana \& Safitri, 2014).

Sunscreen sangat penting bagi kulit remaja, karena pada usia remaja, kulit wajah sudah mulai terpapar sinar matahari akibat tingginya aktivitas diluar ruangan, namun pemilihan sunscreen yang baik sangat penting dilakukan agar kulit tidak menjadi lebih bermasalah akibat bahan-bahan kimia yang terkandung dalam produk sunscreen tersebut. Beberapa produk sunscreen yang beredar di pasaran banyak mengandung bahan kimia yang berbahaya bagi tubuh sehingga mengharuskan masyarakat untuk lebih hati-hati dalam menentukan produk sunscreen yang akan digunakan. Pengetahuan remaja mengenai manfaat serta pentingnya penggunaan sunscreen dalam kehidupan sehari-hari perlu ditingkatkan untuk menghindari penggunaan produk yang berbahaya bagi tubuh. Iklan dan rekomendasi dari teman untuk memilih suatu produk sunscreen menjadi pengaruh besar pada kalangan remaja. satu usaha yang dapat dilakukan yaitu melakukan kegiatan penyuluhan mengenai pentingnya penggunaan sunscreen yang aman dalam kehidupan sehari-hari. Pengetahuan dan kewaspadaan mitra dalam memilih produk sunscreen masih relatif rendah sehingga 
memerlukan edukasi dan sosialiasi mengenai keamanan produk tersebut. Selain keamanan produk sunscreen, informasi penting yang perlu diberikan kepada mitra adalah mengenai penandaan produk sunscreen tersebut. (Supriningrum \& Jubaidah, 2019). Tujuan dari pengabdian ini adalah untuk untuk memberikan Pengetahuan siswa-siswi SMA Islam Sabilillah Malang mengenai manfaat serta pentingnya penggunaan sunscreen dalam kehidupan sehari-hari khususnya bagi para remaja.

\section{Metode Pengabdian}

Pengabdian ini dilaksanakan dengan metode penyuluhan. Kegiatan pengabdian dilaksanakan secara online melalui platform Zoom, mulai dari perencanaan hingga pelaksanaan dalam waktu 1 bulan dengan sasaran adalah para siswa dan siswi di SMA Islam Sabilillah Malang. Kegiatan ini dihadiri oleh 30 responden melalui akun Zoom masingmasing. Kegiatan pengabdian ini dilakukan dengan beberapa tahapan yaitu sebagai berikut :

1) Persiapan Kegiatan

Tahapan awal dari kegiatan pengabdian ini adalah mempersiapkan segala kebutuhan penyuluhan seperti platform Zoom (Hidayatulloh et al., 2021), soal-soal yang digunakan untuk pre dan post test, kemudian materi pengabdian yang akan diberikan, dan juga absensi untuk diisi oleh responden.

2) Pembukaan Kegiatan

Pada inti kegiatan yang dilaksanakan pada tanggal 21 Juni 2021, dimulai pada pukul 08.00 WIB yang ditandai dengan seluruh siswa dan siswi mulai memasuki Zoom.

3) Kegiatan Pre-test.

Kegiatan ini kemudian diawali dengan melakukan pre test oleh peserta yang telah disiapkan oleh tim panitia pengmas. Pre-test dibagikan dalam bentuk online menggunakan platform google form dan peserta tinggal mengisi saja jawabannya.

4) Kegiatan Penyuluhan

Kegiatan inti dari pengabdian kali ini adalah dengan memberikan penyuluhan kepada peserta mengenai penggunaan sunscreen pada kulit remaja. Beberapa kegiatan pengabdian yang banyak dilaksanakan selalu menggunakan metode ceramah untuk memberikan materi kepada peserta (Atmadani et al., 2021; Atmadani \& Hidayati, 2020; Indrawati et al., 2021; Rahman et al., 2021; Yunita \& Atmadani, 2021). Materi yang telah disiapkan, dibuat dalam Microsoft Power-point (Bartsch \& Cobern, 2003), dan dipresentasikan kepada peserta melalui Platform Zoom. Peserta yang ingin bertanya dipersilakan mengisi pada kolom chat yang telah ada pada Zoom. Materi pada penyuluhan ini antara lain adalah edukasi tentang bahaya bahan kimia yang terkandung dalam sunscreen serta manfaatnya bagi kulit, memberikan informasi mengenai manfaat sinar UV bagi kesehatan tubuh gunanya dalam memutus mata rantai penularan Covid-19, serta memberikan informasi mengenai bagan apa saja yang memiliki fungsi sebagai sunscreen. Kegiatan penyuluhan ini disampaikan oleh para mahasiswa Farmasi Universitas Muhammadiyah Malang yang dibimbing oleh Ibu Apoteker Rizka Novia Atmadani,M.Sc yang juga memantau materi serta jalannya kegiatan melalui Zoom.

5) Kegiatan Post-test

Kegiatan ini kemudian diakhiri dengan melakukan post-test oleh peserta yang telah disiapkan oleh tim panitia pengmas dalam bentuk Google form. 
6) Penutupan

Acara terakhir sebelum berakhirnya kegiatan pengabdian adalah dengan memberikan kesempatan bagi seluruh peserta untuk bertanya serta apabila yang mau berdiskusi. Setelah tidak ada pertanyaan dari responden, maka kegiatan pengabdian ini ditutup dengan foto Bersama secara virtual.

\section{Hasil Pengabdian dan Pembahasan}

Untuk memulai kegiatan pengabdian ini yaitu dengan melakukan persiapan. Sembilan hari sebelum melaksanakan kegiatan penyuluhan yakni pada hari Jumat tanggal 28 Mei 2021, Koordinasi secara daring dengan pihak sekolah dilakukan agar penyuluhan dapat dilaksanakan. Karena siswa dari SMA tujuan yang bisa ikut tidak banyak maka kami melakukan penyebaran poster agar kuota partisipasi dapat terpenuhi. Hari jumat malam kami melakukan gladi kotor dan hari sabtu kami melalukan gladi bersih. Saat hari penyuluhan pukul 07.00 kami melakukan percobaan kembali agar tidak ada kendala pada platform yang kami gunakan yaitu Zoom. Tidak hanya itu, tim juga menyiapkan materi yang dibimbing oleh ketua tim yaitu Ibu Apoteker Rizka Novia Atmadani, M.Sc terkait materi-materi yang akan disampaikan. Setelah mendapatkan materi, tim Menyusun item-item pertanyaan yang akan digunakan pada pre dan post-test.

Penyuluhan dalam kegiatan pengabdian dimulai pada pukul 09.00 WIB karena menunggu para peserta masuk ke platform Zoom. Sambil menunggu peserta masuk zoom panitia memutarkan musik dan setelah pukul 09.00 penyuluhan dimulai. Sebelum memulai penjelasan materi para peserta melalukan pre-test terlebih dahulu agar mengetahui pengetahuan awal tentang materi, hasilnya cukup banyak yang mendapatkan hasil dibawah 60 (Gambar 1 hasil nilai pre-test dan post-test). Selanjutnya, penyuluh memberikan materi dengan slide Power-point, yang diawali dengan penjelasan mengenai pengertian Suncreen. Selanjutnya diberikan materi mengenai dampak positif,negative dari sinar UV. Di akhir pemberian materi, diberikan juga beberapa contoh produk Suncreen.

Setelah pemberian materi selesai, dilakukan tanya jawab. Peserta penyuluhan cukup antusias saat sesi tanya jawab ini ada lebih dari 7 pertanyaan yang disampaikan dari beberapa pertanyaan itu terdapat pengalaman pribadi terkait dengan materi penyuluhan. Di akhir kegiatan, peserta melalukan post-test untuk mengetahui apakah peserta paham tentang materi penyuluhan. Dan hasilnya cukup memuaskan, banyak peserta yang mendapatkan nilai 80 keatas. Di akhir acara peserta on-camera untuk sesi dokumentasi sekaligus penutupan acara pengabdian (Gambar 2).

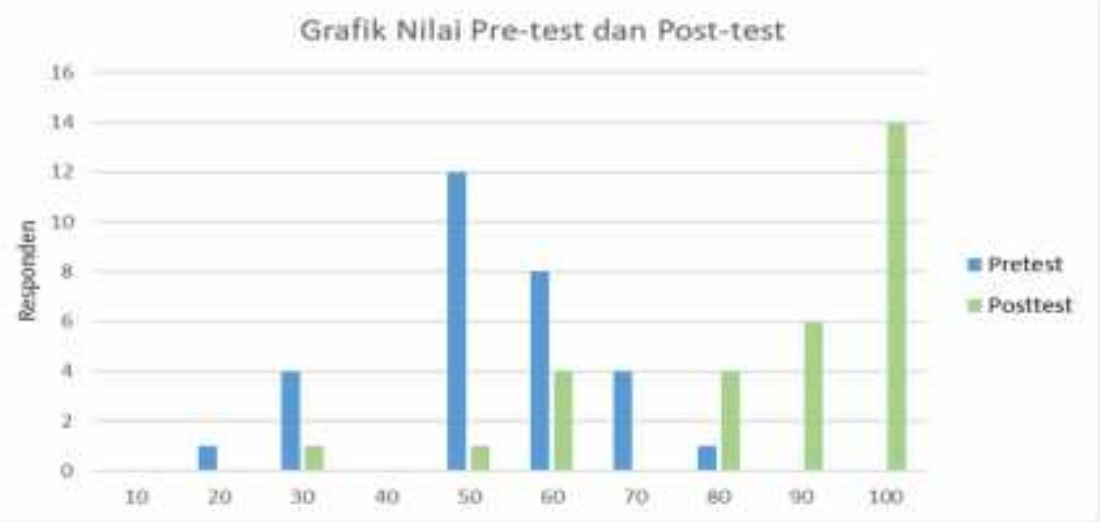

Gambar 1. Hasil nilai pre-test dan post-test para responden 
Bentuk evaluasi keberhasilan dari kegiatan pengabdian adalah memberikan pretest yang bertujuan untuk mengetahui seberapa paham mereka dengan sunscreen, untuk mengetahui juga materi mana yang benar-benar mereka tidak ketahui sehingga kami dapat lebih memfokuskan untuk membahas materi tersebut. Analisa keberhasilan kami adalah dari perhatian dan respon peserta penyuluhan secara umum baik dan dapat dilihat dari keantusiasan peserta saat diskusi. Salah seorang siswa juga bertanya dari pengalaman pribadi. Dari segi proses penyuluhan yang meliputi pemberian materi dan sesi diskusi, pemberian materi dan diskusi berlangsung dengan baik terlihat dari adanya komunikasi antara peserta. Keberhasilan penyuluhan dinilai dengan adanya peningkatan pengetahuan siswa-siswi tentang pentingnya pengunaan suncreen dinilai berdasarkan ketepatan dalam menjawab postest diakhir acara. Dilihat dari Grafik diatas partisipan yang mengikuti pretest dan postest dengan jumlah yang berbeda.
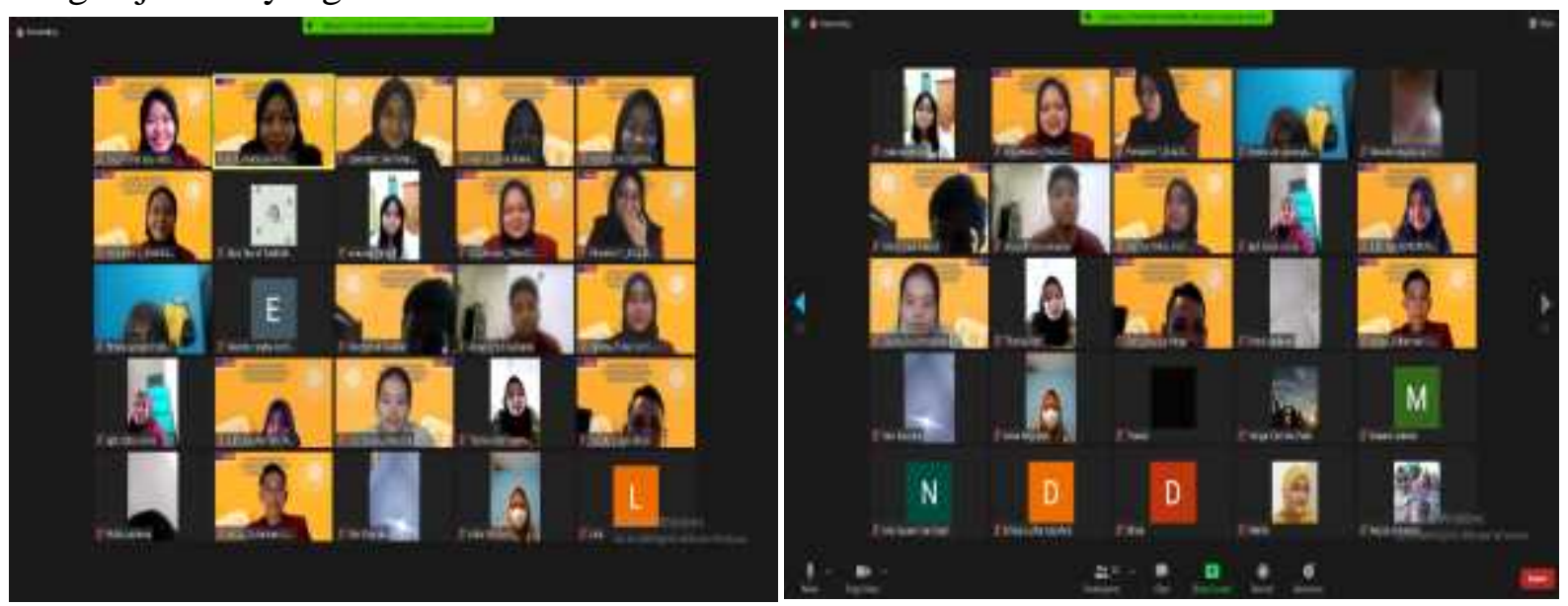

Gambar 2. Dokumentasi Peserta dan Panitia Kegiatan Pengabdian

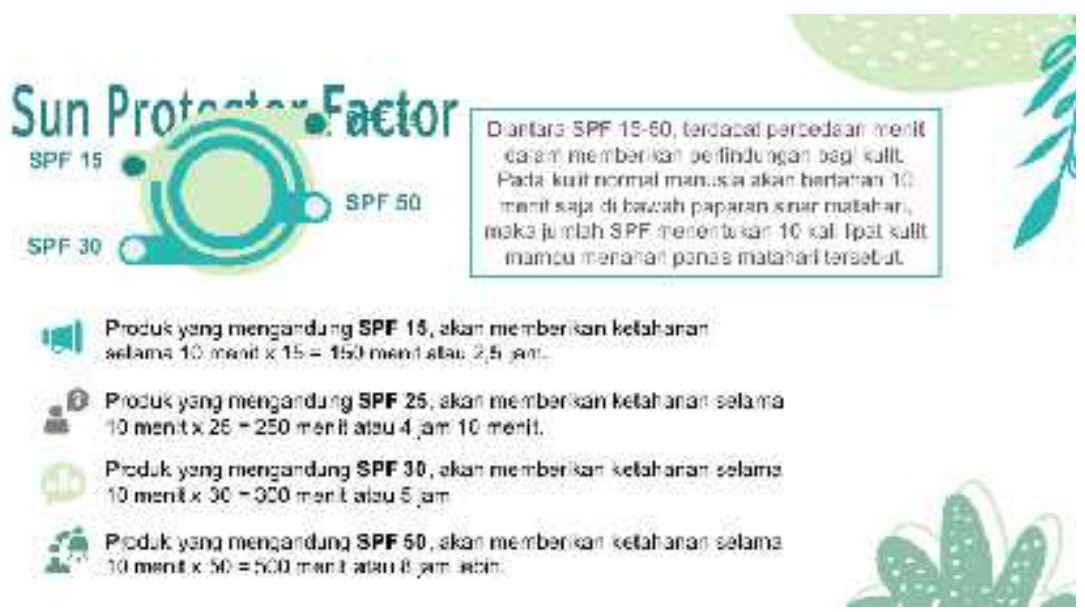

Gambar 3. Salah Satu Materi pada Slide Power-Point

Berdasarkan hasil pengabdian diatas, untuk terus meningkatkan pengetahuan remaja baik dibidang penggunaan perawatan kulit hingga kesehatan tubuh, perlu dilakukan penyuluhan berkelanjutan yang rutin. Penyuluhan kesehatan rutin dapat dilakukan 3 bulan sekali dengan topik yang berbeda untuk memaksimalkan pengetahuan kesehatan siswa-siswi SMA Islam Sabilillah Malang. Kegiatan penyuluhan kesehatan remaja juga dapat diperluas dengan bekerjasama dengan pihak sekolah lain. 


\section{Kesimpulan}

Berdasarkan dari kegiatan pengabdian masyarakat yang telah dilakukan dapat disimpulkan bahwa: (1) Para responden mampu menerima kegiatan pembelajaran melalui slide Powerpoint yang dilaksanakana melalui Zoom sesuai dari tujuan pengabdian yaitu responden dapat menerima edukasi yang kami salurkan melalui online. (2) Terdapat peningkatan pengetahuan tentang penggunaan sunscreen dari nilai pre dan post-test yang dilaksanakan.

\section{Saran}

Saran yang dapat diberikan berdasarkan evaluasi kegiatan pengabdian yang telah dilakukan adalah (1) Karena pelaksanaan pengabdian adalah melalui online dengan platform Zoom, maka sebaiknya untuk kegiatan berikutnya dapat menggunakan sinyal internet yang lebih kuat supaya tidak ada kendala saat pengabdian. (2) Bagi responden yang aktif bertanya dapat diberikan hadiah (reward) supaya semangat untuk mengikuti kegiatan pengabdian selanjutnya.

\section{Daftar Pustaka}

Atmadani, R., \& Hidayati, I. (2020). Pelatihan Apoteker Cilik dan DaGuSiBu bagi Siswa SDN Losari di Singosari, Kabupaten Malang. Jurnal Pengabdian UNDIKMA, 1(2), 77-81. doi:https://doi.org/10.33394/jpu.v1i2.2966

Atmadani, R. N., Yunita, S. L., Hidayati, I. R., Aldila, A. O., \& Rizqi, F. D. (2021). Penyuluhan Perilaku Hidup Bersih dan Sehat (PHBS) sebagai Upaya Preventif dalam Memutus Rantai Penyebaran Covid-19 pada kalangan Mahasiswa Baru Farmasi. To Maega: Jurnal Pengabdian Masyarakat, 4(2), 153-159.

Bartsch, R. A., \& Cobern, K. M. (2003). Effectiveness of PowerPoint presentations in lectures. Computers \& Education, 41(1), 77-86.

Cahyono, W. E. (2005). Pengaruh penipisan ozon terhadap kesehatan manusia. Semnas Penelitian, Pendidikan Dan Penerapan MIPA, 208-214.

Hidayatulloh, A., Rijal, K., Pratama, I., \& Malikah, Hr, B. (2021). Pelatihan Pembelajaran Daring Berbasis Zoom untuk Guru MA NW Kabar Kabupaten Lombok Timur. Jurnal Pengabdian UNDIKMA, 2(1), 115-119. doi:https://doi.org/10.33394/jpu.v2i1.3581

Indrawati, I., Santosa, F., Bahri, S., \& Samsuriadi, S. (2021). Edukasi Kesehatan Masyarakat Melalui Disinfaksi dan Penggunaan Masker Sebagai Upaya Pencegahan Penyebaran Virus Covid-19 di Panti Asuhan Al-Isti' anah Kediri Kabupaten Lombok Barat. Jurnal Pengabdian UNDIKMA, 2(1), 104-109. doi:https://doi.org/10.33394/jpu.v2i1.3713

Isfardiyana, S. H., \& Safitri, S. R. (2014). Pentingnya melindungi kulit dari sinar ultraviolet dan cara melindungi kulit dengan sunblock buatan sendiri. Jurnal Inovasi Dan Kewirausahaan, 3(2), 126-133.

Rahman, A., Suhaeb, F., \& Najamuddin, N. (2021). Sosialisasi Gerakan Masyarakat Hidup Sehat di Desa Bulutellue Kabupaten Sinjai Provinsi Sulawesi Selatan. Jurnal Pengabdian UNDIKMA, 2(1), 9-17. doi:https://doi.org/10.33394/jpu.v2i1.3728

Supriningrum, R., \& Jubaidah, S. (2019). Penyuluhan Kosmetika Aman dan Identifikasi Merkuri dalam Kosmetika. Jurnal Abdimas Mahakam, 3(2), 136. https://doi.org/10.24903/jam.v3i2.505

Yunita, S. L., \& Atmadani, R. N. (2021). IBM DAGUSIBU OBAT DAN PEMERIKSAAN KESEHATAN BAGI PEKERJA MIGRAN INDONESIA (PMI) DI TAIPEI, TAIWAN. SELAPARANG Jurnal Pengabdian Masyarakat Berkemajuan, 4(2), 205209. 